\title{
Gender differences in couples' matrimonial property regime in Italy
}

Romina Fraboni, Senior Researcher, Istat - Italian National Institute of Statistics, Via Cesare Balbo 16 - 00184 - Rome, Italy, +39 0646736303 fraboni@ istat.it

Agnese Vitali, Associate Professor of Demography, Department of Sociology and Social Research, University of Trento, Via Verdi, 26 - 38122 Trento, Italy, agnese.vitali@unitn.it

\section{Acknowledgments:}

This research was funded by the Economic and Social Research Council under the Future Research Leaders grant 'Female-breadwinner Families in Europe' grant reference number ES/N00082X/1. We wish to thank Léa Pessin and Helen Kowalewska for their helpful comments on earlier versions of the paper.

Running title: Gender differences in matrimonial property regime

Objective: This study investigates the characteristics of spouses who choose to pool their economic resources in Italy.

Background: If resource pooling is common among male-breadwinner couples, expectations regarding resource pooling are mixed for female-breadwinner couples or, more generally, for couples with wives who are economically advantaged compared to their husbands. This study asks whether resource pooling strategies differ between couples with economically-advantaged husbands, couples with economically-advantaged wives and couples where spouses have similar economic resources.

Method: The paper uses an objective measure of pooling of wealth available for Italy at the time of marriage: the matrimonial property regime, indicating the choice between a shared or separate ownership of assets accumulated during marriage. Using data from the 2015 marriage 
register, the paper models the probability that a couple chooses the community of property with a logistic regression model.

Results: Couples with husbands who were economically advantaged compared to their wives (i.e., the husband was older, more educated, or employed with a non-employed wife) were more likely to choose the community of property compared to couples with similar resources (both spouses were employed, of similar age or educational attainment); conversely, couples with economically advantaged wives, were more likely to choose the separation of property.

Conclusion: Economically-advantaged women seem to be "undoing gender" by protecting their economic resources via the separation of property.

Keywords: Gender; Family economics; Family resource management; Marriage; Money management.

Since the Family Law was established in 1975, at marriage Italian couples are asked to decide upon the matrimonial property regime that they want to adopt. During or after the wedding ceremony, in both civil and religious marriages and at the presence of their witnesses, the spouses are asked by the wedding official whether they want to opt for the community or the separation of property. In case of divorce or separation, family assets are distributed equally among spouses who opted for the community of property, regardless of whether the assets were purchased jointly or separately. Under the separation of property, spouses maintain sole ownership of assets accumulated during marriage.

The choice over the community or separation of property has a long-lasting effect on spouses' wealth and their right to use, sell and buy property because it regulates the ownership (joint or separate, respectively) of the assets accumulated during marriage. The matrimonial property regime represents an objective measure of resource pooling among spouses that refers 
specifically to the allocation of wealth. Hence, the matrimonial property regime can offer a different perspective to the study of resource pooling, building on previous work that has used self-reported measures only, such as control, management and use of economic resources (see e.g., Lundberg \& Pollak, 1996; Pahl, 1995). Because the matrimonial property regime is recorded in the marriage certificate, such information is available for the whole population marrying in a given year from the marriage register. This allows us to study population subgroups, including female-breadwinner couples (i.e., couples with employed wives and nonemployed husbands), whom we would not be able to capture in sample surveys.

The property regime also has the advantage of measuring the preference regarding (one aspect of) resource pooling at the time of marriage (Burgoyne et al., 2006). The choice of property regime reflects couples' relationship expectations and cultural norms at marriage, before they are influenced by later transitions, such as childbearing, which can result in the acceptance of more traditional gender roles (Burgoyne et al. 2006). By using a measure of resource pooling at the time of marriage, we can describe the demographic and economic characteristics of spouses (e.g., age, educational attainment, employment status) at the time when the decision regarding the separation or pooling of assets is made. Thus, the study addresses a shortcoming of previous studies, in that they observe the characteristics of spouses at the time of the survey only, even if the decision over resource management was taken long before the survey date.

Like other institutions introduced in Italy by the 1975 Family Law, the property regime was inspired by patriarchal values regulating the family life (Rheinstein, 1975): the breadwinner-home-maker couple was the norm and wives were largely economically dependent on their husbands (Saraceno, 1994). The decision to establish the community of property as the default property regime was justified on the grounds that shared ownership of property could foster greater equality between spouses, independently of their economic role 
outside the household. Hence, it could economically protect (non-working) wives during marriage and in case of divorce (Barbagli, 1993; Pocar \& Ronfani, 1978). The tendency towards sharing economic resources equally among spouses was common to other developed countries too during the 1970s and 80s (Kenney, 2006; Rešetar, 2008).

Since the 1970s, however, Italian wives have become more economically independent. For example, $66.0 \%$ of wives are employed at the time of marriage in 2015 , up from $55.8 \%$ in 1975 (Istat, 1978 and 2016). In addition, a new couple-type has started to emerge in which the economic dependence of spouses is reversed: the female-breadwinner couple (i.e., with an employed woman and non-employed man). In 2015, female-breadwinner couples represented $14.3 \%$ of all breadwinning couples (i.e., only one partner employed) up from $6.9 \%$ in 2008 (own elaborations on data from Labour Force Survey). The emergence of couples with reversed gender roles compared to the traditional norms has been particularly relevant following the 2008 economic crisis and is common to other Southern-European countries, which, like Italy, were hardest hit by the crisis (Vitali \& Arpino, 2016). Whereas the community of property was the norm for the traditional male-breadwinner couples of the past (Barbagli, 1993; Lundberg \& Pollak, 1996), expectations regarding resource pooling are mixed for couples in which the woman works and/or is the breadwinner (Kenney, 2006; Lott, 2017; Pepin, 2017; Tichenor, 1999; Yodanis \& Lauer, 2007).

This paper studies the characteristics of spouses who opt for the community vs. the separation of property among the 2015 marriage cohort. We describe the property regime across couples where wives are (i) economically disadvantaged; (ii) economically advantaged, (iii) with the same economic characteristics as their husbands. By exploring the links between the chosen property regime and the spouses' (in)equality in terms of their economic characteristics, we shed light on how modern couples' resource pooling strategies potentially vary according to the gender of the economically (dis)advantaged spouse. 


\section{WHY CHOOSE THE COMMUNITY OF PROPERTY AT MARRIAGE?}

Under the community of property, spouses are requested to share jointly any decision pertaining to the 'extraordinary' administration of their assets that will alter the structure and consistency of goods (e.g., housing, new investments etc.). In case of divorce, they will share equally the assets accumulated during marriage, regardless of whether both spouses equally contributed to the original purchase. The community of property encompasses properties purchased during marriage including vehicles, rental income derived from properties, and revenue from business. Assets acquired prior to marriage, labour income, and assets received as inheritance are not part of the community of property. Spouses can opt out of the community of property by choosing the alternative separation of property, under which each spouse maintains sole ownership of the assets that he/she accumulates during marriage.

The meaning of marriage has changed over time, as the 'companionate' marriage has declined in favour of the 'individualized' marriage (Cherlin, 2004). Consequently spouses today increasingly maintain their own identities and economic independence during marriage (Lauer \& Yodanis, 2011). Accordingly, couples today tend to keep at least part of their economic resources separate (Burgoyne et al., 2006; Pahl, 2005), with fewer couples choosing the community of property at marriage. Table 1 shows how the share of couples opting for the community of property has gradually declined from $81.2 \%$ among the $1975-79$ marriage cohorts to about $50 \%$ in 2000 and $29.0 \%$ in 2015.

\section{[Table 1 about here]}

What is the role of the community of property today and who are the spouses who choose the community as their matrimonial property regime? Below, we review two alternative perspectives: the cultural perspective and the economic perspective. Both perspectives explicitly acknowledge differences in the spouses' economic characteristics as an explanation 
for the choice of matrimonial property regime. In addition, we review the role of other sociodemographic characteristics of the spouses.

In this paper, economic differences among spouses are assumed whenever spouses differ in terms of their education, employment status, age or nationality. Clearly, the breadwinning spouse has an economic advantage compared to an unemployed or inactive spouse. Similarly, the higher-educated spouse is likely to have higher earnings compared to a lower-educated spouse. For example, women who are more educated than their partners are, in general, less economically dependent (Bianchi, Casper \& Peltola, 1999) and more likely to provide the largest share of the household income (Bloemen \& Stancanelli, 2015; Raley, Mattingly \& Bianchi, 2006). Recent studies have shown that the diffusion of couples with women as main earners is linked to the increase in educational hypogamy, whereby the woman is more educated than her partner (Esteve et al., 2016; Klesment \& Van Bavel, 2017). If age is a proxy for work experience, job seniority and higher earnings, all else being equal, the older spouse can be considered economically advantaged compared to the younger spouse (England \& McClintock, 2009; Hakim, 2010). Indeed, previous studies have documented that the main earner in a couple tends to be older than the spouse (Coles \& Francesconi, 2011; Bloemen \& Stancanelli, 2015). Finally, intermarriage between an Italian and a foreign spouse may too represent a marriage in which one of the spouses is disadvantaged compared to the other, as the foreign population is exposed to a higher risk of unemployment, underemployment and pay discrimination than the Italian population (Strozza \& De Santis, 2017). We, therefore, define an economically disadvantaged spouse as the spouse who is less educated or younger than the other spouse, unemployed or inactive (with an employed spouse) or of foreign origin (with an Italian spouse). As predicted by resource theory (Blood \& Wolfe, 1960), we assume that the economically advantaged spouse (i.e., the older, more educated, breadwinner, Italian spouse) will have a major weight in the decision over separation vs. community of property. Our 
predictions are based on the comparison of three couple-types: couples with economically advantaged women, couples with economically advantaged men, and couples in which both spouses share similar economic characteristics.

\section{Spouses' relative resources: The economic perspective}

The economic perspective supports the idea of the 'individualized' marriage and with it the importance of the self, personal choice and freedom. The economic perspective goes against the ideal of romantic love, affection and altruism that characterizes the companionate marriage, and which would instead predict spouses to commit financially by sharing their resources, ignoring their particular economic interests (Billari \& Liefbroer, 2016; Burgess \& Locke, 1945; Cherlin, 2004). Nonetheless, the economic and sociological literatures did not find evidence of a unified model of resource pooling whereby spouses maximize a couple-specific utility and share resources equally among them. Such literatures have instead found support for the bargaining model (i.e., for the importance of one's own rational choice rather than for a couplebased perspective) (Bennett, 2013; Grossbard-Shechtman, 1984; Lersch, 2017; Lundberg \& Pollak, 1996; Pahl, 1995; Pollak, 1985).

Arguments based on the rational choice model suggest that spouses would decide between community and separation of property depending on which one maximizes their own individual utility. According to a mere economic interpretation, we would expect spouses who have equal economic characteristics, and so are able to support themselves, to be indifferent to the choice between separation and community of property. Conversely, economically disadvantaged spouses would prefer the community of property because it provides access to their spouses' resources. Instead, economically-advantaged spouses would choose separation of property to protect their resources. The preferences of both spouses are considered when choosing the matrimonial property regime because the couple will try to minimise the 
transaction costs associated with the management of resources and other aspects of married life (Treas 1993). Yet, resource theory (Blood \& Wolfe, 1960) predicts that the spouse with the highest economic resources within the couple has more weight in the bargaining process. It follows, then, that couples in which economic resources are not distributed equally among spouses are more likely to opt for the separation of property compared to couples with similar economic resources.

Rational individuals will also factor in the possibility that the marriage may end in divorce; hence, they may choose the separation of property to avoid economic interdependences with their spouse (Barbagli, 1993; Holland, 2012). Qualitative research has shown that the fear of the costs associated with divorce is indeed widespread among young cohabiting couples in Italy (Vignoli \& Salvini, 2014).

Finally, separation of property can be considered as a rational decision when one (or both) spouses are self-employed. In fact, the law imposes that when self-employed businesses go bankrupt, personal resources of the self-employed and those of his/her family members will be used to repay the business' debts. Opting for the separation of property in this case would protect the family assets against entrepreneurial risks.

To sum up, according to the economic perspective, we shall expect the community of property to be chosen less often by couples where there is a disparity among spouses in terms of their economic resources, compared to couples where spouses have similar economic resources. However, we shall not expect any difference in the likelihood of choosing the community of property based on the gender of the (dis)advantaged spouse.

\section{Spouses' relative resources: The cultural perspective}

The cultural perspective offers an opposite interpretation. The choice of matrimonial property regime, and more generally the distribution of economic resources among partners, is shaped 
by social norms (Rheinstein, 1975; Lundberg \& Pollak, 1996). When originally introduced in 1975 as the default property regime, the community of property was thought to protect nonworking wives in case of divorce (Barbagli, 1993; Pocar \& Ronfani, 1978). In other words, the original meaning of the community of property was that of guaranteeing economic protection to the spouse (i.e., the wife) who was considered disadvantaged in some way compared to the other spouse (i.e., the husband). Today, however, non-traditional couples with economically advantaged women have come to exist in Italy, and for these couples, it is less clear what we should expect in terms of their preferred property regime. This section reviews the literature on the cultural perspective on resource pooling and formulates hypotheses regarding the couple-types that we expect to be associated with the community of property.

Exchange theory (Davis, 1941; Merton, 1941) has long served as a justification for resource pooling within marriage. The idea is that the breadwinning spouse would reward the other spouse's time spent on housework and childcare activities, by granting access to their economic resources. In principle, exchange theory predicts the exchange of resources to take place as long as the couple operates a separation of gender roles. Hence, according to exchange theory, we should expect community of property to be more often chosen by couples where there is a disparity vs. similarity in economic resources among spouses. In fact, if spouses have access to similar economic resources, they can support themselves and there is no need for normative economic protection of the other spouse. Therefore, such couples should be indifferent to the type of property regime.

According to the non-gendered exchange theory, we would expect a gender reversal in breadwinning not to matter, and protection mechanisms towards the economically disadvantaged spouse to be at play for traditional and non-traditional couples alike so long as there is specialization of work-family roles. This hypothesis, however, has been confuted by empirical studies showing that women who are economically superior to their partners in some 
respects (e.g., by earning more or being the sole breadwinner) continue to do more housework and childcare than their partners (Aassve, Fuochi, \& Mencarini 2014; Tichenor, 2005). If wives are simultaneously both the main breadwinner and the main caregiver for the family, then they would have nothing to reward their husbands for according to exchange theory. Therefore, we would expect couples with breadwinner (or, in general, more economically advantaged) wives to be less willing to opt for the community of property compared to couples with breadwinner husbands. In fact, the idea that the community of property would protect the economically disadvantaged wife was embedded into patriarchal values and a prevailing specialization of gender roles within the family (Becker, 1991; Parsons \& Bales, 1955).

According to the "doing gender" hypothesis, women who are economically superior to their partners contribute more housework and childcare than their partners as a way of compensating for their role in the labour market by reaffirming their role as carers in the private sphere (West \& Zimmerman, 1987). This literature finds that women who earn more than their spouses are not more likely to exert power by solo-managing the family assets compared to couples where both spouses have similar economic characteristics (Yodanis \& Lauer, 2007). In a qualitative study of American couples, Tichenor (1999) found that women who have an economic advantage in terms of income or occupation tended not to exercise more power in their relationships or exert more control over resources. In Tichenor's words, status-reversal wives (i.e., women with an economic advantage compared to their husbands) "back away from whatever power they might derive from their income and status. They either give up control or adopt strategies that make it appear that their husbands are in control" (Tichenor, 1999, p. 649). Breadwinner husbands, instead, tend to retain power over decision-making and asset management and have more control over personal consumption expenditures (Burgoyne \& Lewis, 1994; Pahl, 1995; Vogler \& Pahl, 1993). Following this literature, we shall expect couples with economically advantaged women to be more likely to choose the community of 
property than couples where spouses have similar resources and, possibly, also more likely than couples with economically-advantaged men.

Other empirical studies have found patterns of resource pooling that are inconsistent with the doing-gender hypothesis. These studies find that income pooling is common when wives are economically disadvantaged compared to their husbands, whereas it is less common when wives are economically advantaged. For example, Burgoyne (1990) provided qualitative evidence that wives who were the main breadwinner, even if only temporarily, favoured independently managing the family's economic resources over pooling. Similarly, in a quantitative study of German couples, Lott (2017) showed that the likelihood of joint income pooling declined with women's incomes in favour of the independent management, whereas men's incomes and employment were not associated with the couples' income management system. Furthermore, Lott (2017) found that an increase in women's incomes triggered changes from the pooled towards the independent income management. Similarly, Kenney (2006) found that, in the United States, joint income pooling is more common when women do not contribute or contribute less than $40 \%$ of the total couples' incomes, whereas separate management of incomes controlled by the woman is more common when the woman contributes $60 \%$ or more. Relatedly, in a qualitative study of American couples, Pepin (2017) found that both female and male respondents were more likely to agree that the primary earners should keep a higher portion of his/her income in a separate account when the woman rather than the man was the primary earner.

The existing empirical analyses for the Italian case also suggest that non-traditional couples are more likely to opt for separation rather than community of property. For instance, Barbagli (1993) found an association between the separation of property and female employment between 1976 and 1991. Similarly, Bertocchi, Brunetti, \& Torricelli (2014) found that the probability that wives are responsible for financial and economic decisions increases 
if they are older, better-educated and earn more than their husbands, whereas it decreases when they are employed.

Support for separate management of resources in couples with women as sole or main earners also comes from the empirical economic and psychological literatures. These literatures have found that whereas women in general tend to be more generous and selfless than men, results are more mixed when large monetary incentives are taken into account, as women start to exert more selfish behaviour (Andreoni \& Vesterlund, 2001; Eckel \& Grossman, 1998). Similarly, when monetary benefits are transferred from the household to the woman, she tends to spend more on herself and the children (Attanasio \& Lechene, 2002; Lundberg, Pollak \& Wales 1997).

We could argue that by choosing the separation of property, women protect themselves and their children against the risk of divorce, disagreement over money, and possible irresponsible behaviours with the management of resources and decisions over expenses from their lower-status husbands (Tichenor, 1999). In that respect, Barbagli (1993) theorized that the shift away from community of property might have been driven by working women who wanted to protect their autonomy from the husband's control. A similar interpretation is used by Lott (2017) to explain her empirical finding that separate income management is associated with women's but not men's income and employment.

To sum up, on the basis of our review of the cultural perspective, we expect that when the wife is economically disadvantaged compared to the husband (i.e., when the wife is younger or less educated than the husband, is of foreign origin with an Italian husband, or lives in a male-breadwinner couple), the spouses will be more likely to opt for the community of property compared to when both spouses have equal economic resources. By contrast, the cultural perspective suggests mixed expectations when the husband is the economically disadvantaged spouse. According to exchange theory and the empirical literature on resource pooling, we 
should expect community of property to be more likely for couples with an economicallydisadvantaged wife than in couples with an economically-disadvantaged husband or with economically equal spouses. According to the 'doing gender' hypothesis, instead, we should expect community of property to be more likely for couples with an economically disadvantaged husband or with an economically disadvantaged wife than for homogamous couples.

\section{Education, marriage ritual and place of residence}

Separation of property can be considered a 'modern' family behaviour, which stems from individualism, autonomy, individualized marriage, the decreasing importance of the family as an institution, independence and non-traditional gender attitudes (Cherlin, 2004; Lesthaeghe \& Neels, 2002; Pahl, 1989). Like other 'new' ideas and behaviours, we expect that such preference is predominant among the non-religious as well as higher-educated individuals living in urban areas (Rosina \& Fraboni, 2004). Confirming this hypothesis, Barbagli (1997) showed that between 1976 and 1991, the change from community to separation of property in Italy was driven by more secularized and more educated individuals, as well as couples with employed wives. Similarly, Bayot \& Voena (2014) showed that the probability of choosing the separation of property has been higher among couples with highly-educated, full-time employed women since 1995.

Because the community of property can be regarded as a 'traditional' marital behaviour, we expect it to be associated with traits that are resistant to change, such as religious beliefs, low education and rural contexts. Education is, we expect, a particularly important correlate for the matrimonial property regime. Couples with homogamous highly-educated spouses are more open to non-traditional behaviours, are more gender-egalitarian, and are less likely to divorce (Bryant 2003; Härkönen \& Dronkers, 2006). Thus, we expect couples with 
homogamous highly-educated spouses to be least likely to choose community of property, followed by couples with at least one highly-educated spouse.

Religious individuals are more likely to comply with a traditional vision of marriage, to retreat from divorce, and to abide to the Catholic precept of sharing; therefore, they are more likely to opt for the community of property. From our data we do not have information on religion or religiosity, but we can rely on available information on the religious vs. civil ritual at marriage, which we use as proxy for religiosity. Previous studies suggest that the choice for religious ceremonies may be the product of tradition and not capture effectively individuals' religiosity (Vignoli \& Salvini, 2014); hence, we need to bear in mind that with our indicator, we may be measuring attachment to age-old tradition and habits rather than religiosity tout court. In this vein, Ruiu and Breschi (2017) find the marriage ritual not to be associated with the matrimonial property regime.

We expect community of property to be especially widespread in the most religious areas of Italy (i.e., the North-East, the South and the two main islands of Sicily and Sardinia). Most of these regions (i.e., Veneto and Trentino-Alto Adige in the North-East and all the regions in the South and Islands, except for Abruzzo) voted against the introduction of the divorce law in the 1974 referendum, whereas the rest of the country voted in favour. Moreover, according to Hajnal (1983), historically-rooted regional differences exist in nuptiality patterns in Italy: to the West of the line between Saint Petersburg and Trieste, marriage is late, with a generally small age difference between spouses and a significant proportion of women who remain unmarried compared to the East. A North-South divide also exists in terms of gender roles, that is, gender-egalitarian attitudes are more traditional (Arpino and Tavares, 2013) and female labour-force participation is lower (Istat, 2015) in the South and Islands. Moreover, other dimensions of the territorial context may express the degree of urbanization and attachment to traditionalism: we therefore introduce the place of celebration of the marriage, 
distinguishing between provincial capital city and other municipality. We expect that couples whose marriage was celebrated in a non-capital city will be more traditional and hence more likely to opt for the community of property.

To sum up, we shall expect community of property to be more likely than separation among spouses who are lower-educated, live in rural vs. urban areas in the North-East and South of Italy, who marry according to a Catholic vs. civil ceremony, and among spouses who differ in terms of education, employment status, age and citizenship vs. spouses who have similar characteristics.

\section{METHOD}

\section{Data}

This paper makes use of the 2015 Istat marriage register for Italy. This is an administrative data source collecting socio-demographic information on the spouses whose marriages were celebrated in Italy in $2015(\mathrm{~N}=194,377)$. Among other things, collected information includes the citizenship of both spouses, their age, level of education, employment status, place of celebration of the wedding, and choice of matrimonial property regime, all measured at the time of marriage. For the analyses, we exclude 6,326 cases of marriages between two foreign spouses, because their choice of matrimonial property regime might be influenced by the culture of their country of origin. Also, we exclude second or higher-order marriages $(\mathrm{N}=$ $32,132)$ and focus on first marriages only in which neither spouse was married before. The final number of observations is 155,919 marriages.

\section{Procedure}

Our dependent variable is the probability that a couple chooses the community vs. separation of property at first marriage. A logistic regression model is used to explore the links between 
the spouses' economic (in)equalities and their likelihood of choosing the community of property.

The choice of the independent variables follows the theoretical discussion in the previous sections. To measure the spouses' level of education, we distinguish between couples with spouses both having the same level of education (low; medium -reference group-; high); couples with wives more educated than husbands (husband low-medium and wife high educated; husband low and wife medium) and couples with husbands more educated than wives (husband high and wife low-medium; husband medium and wife low). Low education includes up to lower secondary, medium education refers to upper secondary, and high refers to tertiary education. To measure the spouses' employment status, we consider: dual-earner couples, distinguishing between couples with both spouses employed as employees (reference group) and couples where at least one spouse is self-employed; couples where only the husband is employed, distinguishing between self-employed and employee; couples where only the wife is employed, again distinguishing between self-employed and employee; and jobless couples. We include the spouses' citizenship (both spouses are Italian -reference group-, Italian wife and foreign husband, Italian husband and foreign wife); the age of the husband (both linear and quadratic term) and the age difference among spouses (same age, i.e., the age-gap among partners ranges between -3 and +3 years -reference group-; the husband is more than 3 years older than the wife; the wife is more than 3 years older than the husband; the three-year cut-off takes into account the observed average age difference among spouses in 2015, i.e., 2.8 years in favour of the husband). Finally, we include the macro-area where the wedding was celebrated (North-West; North-East; Centre -reference group-; South; Islands); the type of municipality (provincial capital city vs. other municipality -reference group-) and religious vs. civil marriage ceremony. Table 2 provides summary statistics of all variables used in the regression models. 
We run two logistic regression models. Model 1 includes all the above-mentioned variables. Model 2 introduces an interaction between the macro-area of wedding celebration and whether the municipality of celebration was a provincial capital city. For ease of interpretation, we use graphical representations showing the average predicted probability of choosing the community of property at marriage for those explanatory variables with three or more categories.

[Table 2 about here]

\section{RESULTS}

Results from the logistic regression model, presented in Table 3, allowed us to identify the characteristics of spouses who opt for the community of property in contemporary Italy. The estimated coefficients of explanatory variables are robust to the introduction of the interaction term in Model 2; hence, we discuss results presented in Model 2, unless explicitly indicated.

We found a clear educational gradient in the choice of matrimonial property regime: as shown in Figure 1, the probability of choosing the community of property, after controlling for the other variables in the model, was lowest among homogamous couples with both highlyeducated spouses, followed by spouses who were medium educated and those who were low educated. Among heterogamous couples, the likelihood of choosing the community of property increased as the wife's educational attainment decreased. The probability of choosing the community of property was highest for couples with medium-educated men and low-educated women and for couples with high-educated men and low or medium-educated women. The community of property was less common among hypogamic couples (i.e., couples where the woman was more educated than the man) than among hypergamic couples (i.e., couples where the woman was less educated than the man).

[Table 3 about here] 
[Figure 1 about here]

The spouses' employment situation was also associated with their choice of matrimonial property regime (Figure 2). Community of property was significantly less likely when at least one spouse was self-employed compared to all other couple-types. Dual earners with both spouses employed as employees were more likely to opt for the community of property compared to dual earners with at least one self-employed spouse, all else being equal. Similarly, in male-breadwinner couples where the man was employed as an employee, the couple was more likely to opt for the community of property compared to male-breadwinner couples with a self-employed man. The difference was present also for female-breadwinner couples, although we note that the number of couples with self-employed female breadwinners was small compared to other couple-types; hence, results for this couple-type must be interpreted with care. These results are in line with our expectations given the legal implications of self-employment on the family assets in case of bankruptcy.

Of all couple-types, male-breadwinner couples with men employed as employees showed the highest probability of choosing the community of property, followed by jobless couples. Looking at couples with no self-employed spouses, for male-breadwinner couples, the community of property was significantly more likely than it was among dual-earner or femalebreadwinner couples. For female-breadwinner couples the probability of choosing the community of property was similar to that for dual-earner couples. We know from previous literature that marriage is generally associated with a stable employment situation for the man (Vignoli, Tocchioni, \& Salvini, 2016). Hence, couples with employed wives and unemployed or inactive husbands, which represented about $2 \%(\mathrm{~N}=2,965)$ of couples in first marriages, were likely to be a selected group. Furthermore, the predicted probability of choosing the community of property among male-breadwinner couples with men employed as employees appeared to be higher than the predicted probability among female-breadwinner couples with 
women employed as employees; however, we acknowledge that the magnitude of such difference was small.

[Figure 2 about here]

In terms of age differences among spouses, the probability of choosing the community of property was significantly higher when the husband was more than 3 years older than the wife compared to when spouses had an age-gap between -3 and +3 years, whereas the probability was lower when the wife was more than 3 years older than the husband (Figure 3 ). The chosen age-gap captured $58.8 \%$ of marriages among spouses with an age-gap between - 3 and +3 years, however, results were consistent when restricting the definition of age homogamy to partners with the same age (capturing only $9.3 \%$ of marriages among spouses of the same age).

[Figure 3 about here]

The control variable measuring the husband's age showed a positive and quadratic association with the probability of choosing the community of property: couples with older husbands were more likely to opt for resource pooling compared to couples with younger husbands, all else being equal. For example, the predicted probability of choosing the community of property was $35.7 \%$ for a couple with a 20 -year-old husband and declined to $28.4 \%$ and $24.6 \%$ for a couple with a 30 -year-old husband and a 40-year-old husband, respectively.

Community of property was also significantly more likely in marriages between an Italian and a foreign spouse as compared to marriages between two Italian spouses, independently of the gender of the latter, all else being equal. According to Figure 4, the predicted probability of choosing community of property among couples with an Italian wife and a foreign husband was (slightly) higher than among couples with an Italian husband and a foreign wife. This result contradicts our expectation that women who marry an economically- 
disadvantaged spouse will be more likely to choose the separation of property than men in the same situation. Yet, to fully understand this result, one needs to consider the characteristics of mixed marriages in Italy. Marriages between a native husband and a foreign wife accounted for $7.0 \%$ of all marriages, whereas marriages between an Italian wife and a foreign husband accounted for only $2.1 \%$ (Istat, 2016). Gender differences existed regarding the main countries of origin of the foreign spouse: only $7.6 \%$ of Italian men who intermarried did so with a spouse from Western Europe and North America; the corresponding percentage for Italian women who intermarried was $14.8 \%$. Hence, foreign husbands who married Italian women were quantitatively less and more economically advantaged than foreign wives who married Italian husbands.

[Figure 4 about here]

To sum up the results so far, the community of property was associated with couplespecific traits generally linked to a late adoption of new or innovative behaviours, such as lower education and traditional division of gender roles (husbands being the sole breadwinners, older or more educated than their wives), and with exogamous marriages. The findings related to gender double standards provided support for the resource pooling hypothesis: the community of property was more common when the husband was economically advantaged compared to when both spouses had similar characteristics, but it was not more likely if the economically advantaged spouse was the wife.

Looking at the characteristics of the place of celebration, we found that community of property was less likely if the marriage was celebrated in a municipality which was also a capital city (i.e., in a more urban context), as opposed to non-capital cities. Furthermore, according to the estimates from Model 1 in Table 3, as expected, the probability of choosing the community of property was highest in the Catholic regions of the North East of Italy compared to the Central regions. Instead, contrary to our expectations, the probability of 
choosing the community of property was lowest in the traditional regions of the South and Islands. To shed light on this unexpected result, in Model 2, we added an interaction between region and type of municipality (Figure 5). It emerged that in the South, couples were more likely to opt for the community of property if they lived in capital vs. non-capital cities, whereas the opposite was found in other regions.

[Figure 5 about here]

Finally, we found the community of property to be significantly more likely among spouses who opted for a civil rather than religious wedding. According to the descriptive findings reported in Table 2 and against our hypothesis, couples opting for the separation of property were indeed more widespread among religious (74.8\%) than among civil marriages (68.7\%). Our empirical analyses support the findings in Ruiu \& Breschi (2017), who emphasized a disconnection between religious marriages and the choice of community of property among marriages celebrated in Italy in the late 2010s. Our results are also consistent with Vignoli \& Salvini (2014), who found a disconnection between the choice of a Catholic vs. civil ceremony at marriage and the spouses' own religiosity. In their interpretation, the choice of a Catholic ceremony stemmed from tradition and social pressure rather than adherence to Catholic precepts. Such tradition appeared to still be widespread, with $66.4 \%$ of all first weddings celebrated according to a religious ceremony. Still, we acknowledge that Ruiu \& Breschi (2017) found a non-significant association between marital rite of celebration and choice of matrimonial property regime, whereas we found that the community of property was more likely among civil marriages. One explanation for our different finding is that this paper focuses on first marriages celebrated in 2015. Ruiu \& Breschi instead pooled together first and second marriages that were celebrated between 2007-2009. Because divorcees are normally not allowed to re-marry according to a Catholic rite, we would expect their contribution to the propensity to choose community vs. separation of property to operate only via civil ceremonies. 


\section{DISCUSSION}

The increasing labour force participation of women and their increasing economic power relative to men's has triggered a renewed interest in the study of how economic resources are managed among couples (Bennett, 2013; Lersch, 2017; Lott, 2017; Pepin, 2017). The way couples control, manage and use their economic resources is normally studied using measures of income pooling, indicating whether the partners keep separate or joint accounts, and which spouse has the main responsibility for certain household decisions (see e.g., Lundberg \& Pollak, 1996; Pahl, 1995). Instead, this paper makes use of an objective measure of resource sharing among spouses, which refers specifically to the allocation of wealth: the matrimonial property regime, regulating whether the assets accumulated during marriage will be shared equally among spouses or kept separate. This measure is available from the Italian marriage register and allows for studying resource pooling at the time of marriage for all couples who married in a given year.

This paper has asked whether the community of property is preferred by spouses with a disparity of economic resources and whether the choice over the matrimonial property regime is dependent upon the gender of the economically (dis)advantaged spouse. Economic disparities were measured in terms of differences among spouses in education, employment status, age and foreign origin. We find evidence that couples with traditional characteristics, such as low education and living in rural or small urban contexts, show the highest likelihood of choosing the community of property. Furthermore, we find that the choice of the matrimonial property regime is associated with the distribution of economic resources among spouses. However, the choice over community or separation of property depends on the gender of the economically (dis)advantaged spouse. Couples that resemble the male-breadwinner family (i.e., with husbands older or more educated, or employed with a non-employed wife), 
tend to pool their resources using the institution of the community of property at marriage, whereas female breadwinners or couples with age and education imbalance to female advantage (i.e., wives older or more educated) tend to keep their resources separate. Instead, couples with a foreign husband are as likely to opt for the community of property as couples with a foreign wife. We have explained this result in terms of relative frequency and composition of these two different groups: Italian women who intermarry are fewer than Italian men who intermarry and are more likely to intermarry with economically advantaged spouses from developed countries compared to Italian men who intermarry.

So, why do couples with economically disadvantaged husbands reject resource pooling in the form of community of property more than couples which are equivalent in all respects? To answer such questions, it is important to understand the Italian context. Compared to the rest of Europe, Italy ranks as one of the countries with the least widespread gender-egalitarian attitudes and largest gender gap in time devoted to housework (Altintas \& Sullivan, 2016; Arpino, Esping-Andersen \& Pessin, 2015). In a traditional context such as Italy, men and women may find it difficult to accept the economic superiority of women and to 'officialise' it at marriage by choosing the community of property when husbands are not the main breadwinners. Social norms are favourable to protecting women when they are the disadvantaged spouse, given that patriarchal values are still widespread. Social norms, however, are not favourable to protecting men when they represent the economically disadvantaged spouse (Lott, 2017). Women are not used to being the economically advantaged spouse, nor are men used to being economically disadvantaged. Hence, economic resources have different values and meanings depending on the gender of the main provider, especially if men embrace gender-traditional ideologies (Vogler, 1998).

Our study of matrimonial property regime confirms previous empirical findings showing that income pooling is most common when husbands are the main earners and least 
common when wives are the main earners (Burgoyne, 1990; Kenney, 2006; Lott, 2017; Pepin, 2017). Our results support a gendered interpretation of resource theory: in male-breadwinner couples non-working wives are likely to specialize in domestic work and resource pooling in the form of community of property is more likely than in dual-earner couples. Conversely, in female-breadwinner couples, non-working husbands are unlikely to specialise in domestic work; in this case, resource pooling is not justified as a reward for the husband for his homemaking activities. Relatedly, our results are not consistent with the 'doing gender' hypothesis, according to which economically advantaged women avoid exercising power by sharing their resources with their lower-status spouse (Tichenor, 1999; Yodanis \& Lauer, 2007). Economically advantaged women, differently from economically advantaged men, seem to be exercising their power to protect their economic resources from their husbands (Barbagli, 1993; Lott, 2017). Therefore, these couples are "undoing gender" by deviating from traditional gender norms prescribing breadwinning as a typical male trait and opting to retain separate ownership of the assets that will be accumulated during the marriage. In a way, then, nontraditional couples with economically homogamous spouses and especially couples with economically advantaged women appear to be guided by economic considerations leading to the separation of resources rather than protecting the economically disadvantaged spouse with resource pooling.

It is also possible that men who are economically dependent on their spouses are unwilling to opt for the community of property as a way of reaffirming their masculinity. These men may not be willing to accept a matrimonial property regime that aims at fostering economic equality with their higher-earning spouses in case of divorce. Such interpretation, and our empirical evidence -at least for a gender-traditional context such is Italy- goes against the hypothesis of a convergence of preferences between men and women, whereby men, just 
like women, now consider economic resources as an important attribute in their prospective spouse (Sweeney \& Cancian, 2004).

We are not able with register data to investigate the reasons behind the observed doublestandards in resource pooling among partners on the basis of the gender of the economically (dis)advantaged partner, so we leave this to further research with richer data. In the following we do, however, speculate on the consequences of the double standards in resource pooling that we have observed in our study of matrimonial property regime in Italy, and that others have observed in studies of income pooling in other countries.

This paper documents a sharp increase in the percentage of couples opting for the separation of property, which passed from less than $20 \%$ in $1975-1979$ to above $70 \%$ in 2015 and reveals that couples with women who have an economic advantage compared to their partners are the most likely to choose the separation of property compared to any other coupletype. If separate resources are regarded as an indicator of gender equality among spouses (Pahl, 1989), then for Italy the remarkable diffusion of the separation of property over time is at odds with still-prevailing traditional gender norms. Yes, the majority of wives are in employment at the time of marriage, but about a quarter of them leave employment after the birth of a child (Istat 2015). Women who are employed at the time of marriage and who choose the separation of property may become inactive, unemployed or subject to wage penalties after the birth of their children and are therefore still exposed to the risk of being economically worse-off in case of divorce. In a sense, on average, women still represent the economically disadvantaged spouse, especially if they have children.

Therefore, separation of property and, more generally, separate resources, can still be regarded as detrimental for women today in case of divorce, especially if they have children (Barbagli, 1993; Pahl, 2005; Burgoyne et al. 2006). At the time of marriage, when the decision regarding the matrimonial property regime is made, couples do not seem to foresee the possible 
future changes in women's employment status and career prospects (Burgoyne et al. 2006). It seems plausible that couples are more egalitarian at the time of marriage and then revert to more traditional gender roles after childbearing. Longitudinal data would shed light on whether economically-advantaged women revert to a disadvantaged status in case of divorce, should they choose the separation of property.

Our results also bring in the perspective of couples where men are the economically disadvantaged spouse, a type of couple that has been increasing in recent years but has received little interest (Bennett, 2013). We find that economically disadvantaged men are more likely to be under the separation of property regime, and are therefore exposed to the risk of being economically worse-off in case of divorce. This result signals the emergence of inequality in access to family income and wealth for economically disadvantaged men compared to disadvantaged women.

We acknowledge that our study presents some limitations. First, we could only consider the characteristics of spouses as recorded in the marriage register. Whereby certain characteristics are fixed over time, such as nationality and age at marriage, and others, such as educational attainment, are unlikely to change, the employment status of either spouse may change after marriage. However, such changes can only be measured with longitudinal data. Also, we lack information about the house property or the management of the family budget within the couple in everyday life. For instance, it could be that spouses equally share the house property or the bank account in order to compensate for the potential imbalance arising from the separation of property. We also cannot control for the experience of premarital cohabitation, which may be important because cohabiting partners are more likely to keep their economic resources separate (Vogler, Brockmann \& Wiggins, 2008), tend to be less religious and are more often dual-earners and educationally homogamous (De Rose \& Fraboni, 2015) than married individuals. In addition, we lack information on spouses' value orientations or time 
devoted to domestic work. We also do not have information on whether couples had children prior to the wedding, which may be a further reason to choose the community vs. the separation of property. Finally, we cannot control for the absolute value of economic resources, such as the couple's income or wealth. 


\section{List of Tables}

Table 1: First Marriages by Year of Marriage and Matrimonial Property Regime (Percentage of First Marriages)

\begin{tabular}{lcccc}
\hline Year of marriage & \% Community & & Year of marriage & \% Community \\
\cline { 1 - 2 } \cline { 5 - 5 } $1975-1979$ (a) & 81.2 & & 2004 & 44.0 \\
$1980-1984$ (a) & 75.0 & & 2005 & 42.3 \\
$1985-1989$ (a) & 69.2 & & 2006 & 40.9 \\
$1990-1994$ (a) & 62.1 & & 2007 & 38.7 \\
1995 & 59.1 & & 2008 & 37.3 \\
1996 & 56.8 & & 2009 & 35.8 \\
1997 & 54.4 & & 2010 & 33.9 \\
1998 & 52.9 & & 2011 & 33.1 \\
1999 & 51.3 & & 2012 & 31.1 \\
2000 & 49.9 & & 2013 & 30.5 \\
2001 & 48.9 & 2014 & 29.5 \\
2002 & 47.2 & 2015 & 29.0 \\
2003 & 44.7 & & \\
\hline
\end{tabular}

Source. ISTAT - Marriage register (1995-2015) and multipurpose household survey on "Family and Social Subjects" (2009).

Note. Differently than in subsequent tables and figures, where we exclude marriages celebrated between two foreign spouses, here we consider all first marriages celebrated in Italy, because for the 1975-1994 marriage cohorts we cannot identify the nationality of the spouses.

(a) Information on the matrimonial property regime started to be collected by Istat in the Italian marriage register only in 1995. In order to reconstruct the share of couples opting for the community vs. separation of property since its introduction in 1975, we make use of the 2009 multipurpose household survey "Family and Social Subjects" (Istat, 2011). This survey collects retrospective information on the matrimonial property regime at first marriage for all married, separated, divorced and widowed women and for widowed men aged 15 and over and is based on a sample of 24,000 nationally representative households. 
TABLE 2: DESCRIPTIVE STATISTICS OF VARIABLES USED IN REGRESSION MODELS, YEAR 2015

\begin{tabular}{|c|c|c|c|c|}
\hline & \multicolumn{4}{|c|}{ First marriages } \\
\hline & \multicolumn{3}{|c|}{ Matrimonial regime } & \multirow[b]{2}{*}{$\%$ col } \\
\hline & Community & Separation & Total & \\
\hline TOTAL & 27.2 & 72.8 & 100.0 & 100.0 \\
\hline \multicolumn{5}{|l|}{ Couple's type } \\
\hline Both Italians & 26.7 & 73.3 & 100.0 & 92.9 \\
\hline Italian groom, Foreign bride & 33.5 & 66.5 & 100.0 & 5.0 \\
\hline Foreign groom, Italian bride & 37.7 & 62.3 & 100.0 & 2.1 \\
\hline \multicolumn{5}{|l|}{ Age differential } \\
\hline Man $>3$ years older & 27.1 & 72.9 & 100.0 & 38.4 \\
\hline Similar age: $+/-3$ years & 27.3 & 72.7 & 100.0 & 58.8 \\
\hline Woman $>3$ years older & 27.6 & 72.4 & 100.0 & 5.8 \\
\hline \multicolumn{5}{|l|}{ Couple's education } \\
\hline Low-Low & 30.0 & 70.0 & 100.0 & 20.2 \\
\hline Medium-Medium & 27.4 & 72.6 & 100.0 & 32.5 \\
\hline High-High & 22.4 & 77.6 & 100.0 & 17.1 \\
\hline Man Low/Medium-Woman High & 26.2 & 73.8 & 100.0 & 12.9 \\
\hline Man High-Woman Low/Medium & 27.9 & 72.1 & 100.0 & 5.0 \\
\hline Man Low - Woman Medium & 29.3 & 70.7 & 100.0 & 8.9 \\
\hline Man Medium-Woman low & 31.0 & 69.0 & 100.0 & 3.4 \\
\hline \multicolumn{5}{|l|}{ Couple's employment } \\
\hline $\begin{array}{l}\text { Both employed, at least a self-employed } \\
\text { spouse }\end{array}$ & 19.9 & 80.1 & 100.0 & 24.3 \\
\hline Both employed, no self-employed & 29.3 & 70.7 & 100.0 & 39.3 \\
\hline Only man employed as self-employed & 22.9 & 77.1 & 100.0 & 4.4 \\
\hline Only man employed as employee & 30.8 & 69.2 & 100.0 & 21.9 \\
\hline Only woman employed as self-employed & 26.9 & 73.1 & 100.0 & 0.7 \\
\hline Only woman employed as employee & 30.2 & 69.8 & 100.0 & 1.2 \\
\hline Both unemployed/inactive & 31.2 & 68.8 & 100.0 & 8.2 \\
\hline \multicolumn{5}{|l|}{ Rite of wedding ceremony } \\
\hline Religious & 25.2 & 74.8 & 100.0 & 66.4 \\
\hline Civil & 31.3 & 68.7 & 100.0 & 33.6 \\
\hline \multicolumn{5}{|l|}{ Provincial capital city } \\
\hline No & 27.4 & 72.6 & 100.0 & 73.8 \\
\hline Yes & 26.9 & 73.1 & 100.0 & 26.2 \\
\hline \multicolumn{5}{|l|}{ Geographical area of celebration } \\
\hline North-West & 29.1 & 70.9 & 100.0 & 21.4 \\
\hline Nord-East & 31.1 & 68.9 & 100.0 & 15.9 \\
\hline Centre & 29.0 & 71.0 & 100.0 & 17.6 \\
\hline South & 23.9 & 76.1 & 100.0 & 30.7 \\
\hline Islands & 25.2 & 74.8 & 100.0 & 14.4 \\
\hline Age of Man (mean) & 33.9 & 34.3 & 34.2 & \\
\hline $\mathrm{N}$ & 42,456 & 113,463 & 155,919 & 155,919 \\
\hline
\end{tabular}

Source: Istat. Marriage register.

Note. Marriages among two foreign spouses are excluded. 
Table 3: Results from Logistic Regression Model on the Probability of Opting for Community of Property at Marriage, First Marriages of Both Spouses

\begin{tabular}{|c|c|c|c|c|c|c|}
\hline \multirow{3}{*}{ Education (Ref. Medium-Medium) } & \multicolumn{3}{|c|}{ Model 1} & \multicolumn{3}{|c|}{ Model 2} \\
\hline & \multicolumn{2}{|l|}{ Odds Ratio } & \multirow[t]{2}{*}{ Std. Err. } & \multicolumn{2}{|l|}{ Odds Ratio } & \multirow[t]{2}{*}{ Std. Err. } \\
\hline & & & & & & \\
\hline Low-Low & 1.072 & $* * *$ & 0.019 & 1.059 & $* * *$ & 0.019 \\
\hline High-High & 0.896 & $* * *$ & 0.017 & 0.893 & $* * *$ & 0.017 \\
\hline Man Low/Medium - Woman High & 1.009 & & 0.020 & 1.002 & & 0.019 \\
\hline Man High - Woman Low/Medium & 1.161 & $* * *$ & 0.033 & 1.148 & $* * *$ & 0.032 \\
\hline Man Low - Woman Medium & 1.064 & $* *$ & 0.023 & 1.047 & $*$ & 0.023 \\
\hline Man Medium - Woman low & 1.165 & $* * *$ & 0.037 & 1.151 & $* * *$ & 0.037 \\
\hline \multicolumn{7}{|l|}{$\begin{array}{l}\text { Employment status (Ref. Both employed, no self- } \\
\text { employed) }\end{array}$} \\
\hline Both employed, at least one as self-employed & 0.631 & $* * *$ & 0.010 & 0.624 & $* * *$ & 0.010 \\
\hline Only Man employed as self-employed & 0.720 & $* * *$ & 0.022 & 0.722 & $* * *$ & 0.022 \\
\hline Only Man employed, no self-employed & 1.100 & $* * *$ & 0.018 & 1.106 & $* * *$ & 0.018 \\
\hline Only Woman employed as self-employed & 0.780 & $* * *$ & 0.057 & 0.782 & $* * *$ & 0.057 \\
\hline Only Woman employed, no self-employed & 0.940 & & 0.048 & 0.941 & & 0.048 \\
\hline Both umemployed /inactive & 1.056 & $*$ & 0.026 & 1.059 & $*$ & 0.026 \\
\hline Age of Man & 0.931 & $* * *$ & 0.004 & 0.930 & $* * *$ & 0.004 \\
\hline Age of $\mathrm{Man}^{2}$ & 1.001 & $* * *$ & 0.000 & 1.001 & $* * *$ & 0.000 \\
\hline \multicolumn{7}{|l|}{ Age differential (Ref. Similar age: $+/-3$ years) } \\
\hline Man $>3$ years older & 1.050 & $* * *$ & 0.014 & 1.051 & $* *$ & 0.014 \\
\hline Woman $>3$ years older & 0.927 & $* *$ & 0.023 & 0.928 & $*$ & 0.023 \\
\hline \multicolumn{7}{|l|}{ Couple type (Ref. Both Italian) } \\
\hline Man Italian, Woman Foreign & 1.186 & $* * *$ & 0.031 & 1.186 & $* * *$ & 0.031 \\
\hline Man Foreign, Woman Italian & 1.302 & $* * *$ & 0.050 & 1.301 & $* * *$ & 0.050 \\
\hline Provincial capital city (Ref. No) & 0.974 & $*$ & 0.013 & 0.960 & & 0.027 \\
\hline \multicolumn{7}{|l|}{ Geographical area (Ref. Centre) } \\
\hline North-West & 0.983 & & 0.018 & 0.999 & & 0.022 \\
\hline North-East & 1.106 & $* * *$ & 0.022 & 1.135 & $* * *$ & 0.026 \\
\hline South & 0.762 & $* * *$ & 0.014 & 0.712 & $* * *$ & 0.015 \\
\hline Islands & 0.788 & $* * *$ & 0.017 & 0.836 & $* * *$ & 0.021 \\
\hline \multicolumn{7}{|c|}{ Geographical area*Provincial capital city (Ref. Centre, No) } \\
\hline North-West*Provincial capital city & & & & 0.924 & & 0.038 \\
\hline North-East*Provincial capital city & & & & 0.898 & $*$ & 0.039 \\
\hline South*Provincial capital city & & & & 1.351 & $* * *$ & 0.052 \\
\hline Islands*Provincial capital city & & & & 0.827 & $* * *$ & 0.036 \\
\hline Religious Marriage (Ref. Civil) & 0.808 & $* * *$ & 0.011 & 0.807 & $* * *$ & 0.011 \\
\hline Constant & 2.352 & $* * *$ & 0.207 & 2.387 & $* * *$ & 0.211 \\
\hline$N$ & & & 155,919 & & & 155,919 \\
\hline Log likelihood & & & -89596.5 & & & -89506.2 \\
\hline LR chi2(24) & & & 3397.1 & & & 3577.59 \\
\hline Prob > chi2 & & & 0.000 & & & 0.000 \\
\hline Pseudo R2 & & & 0.0186 & & & 0.0196 \\
\hline
\end{tabular}

p-value: $* * *<0.001 ; * *<0.01 ; *<0.05$.

Source. Istat. Marriage register, 2015. 


\section{List of Figures}

Figure 1: Average AdJusted Predictions of OBSERVING COMMUNity OF PROPERTY By COUPLE'S EDUCATIONAL COMPOSITION, WITH 95\% CONFIDENCE INTERVAL

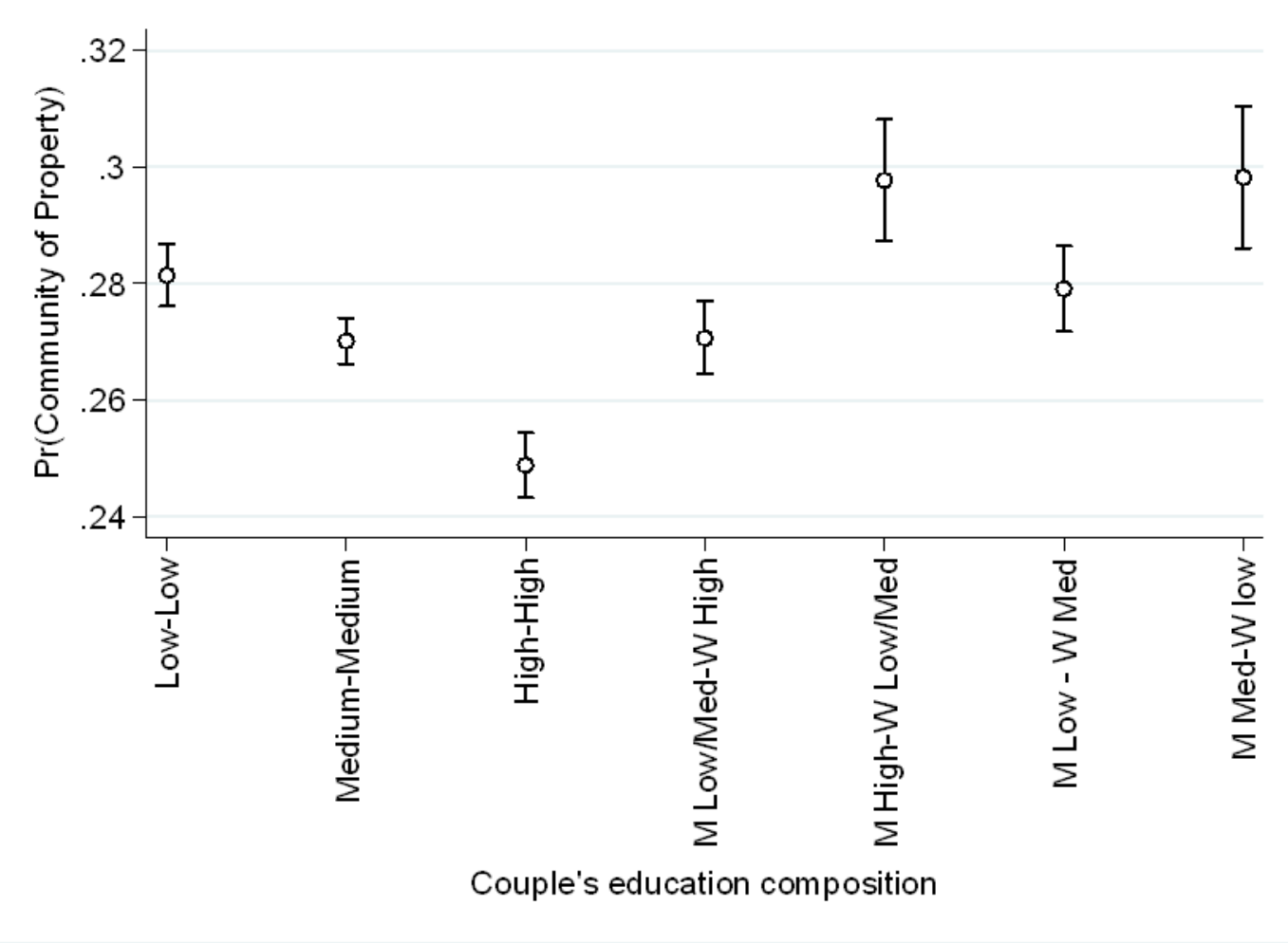

Source. Istat. Marriage register, 2015.

Note. Results from logistic regression Model 2, all controls included. 
Figure 2: Average AdJusted PREDICTIONS OF OBSERVING COMMUNITY OF PROPERTY BY COUPLE'S EMPLOYMENT COMPOSITION, WITH 95\% CONFIDENCE INTERVAL

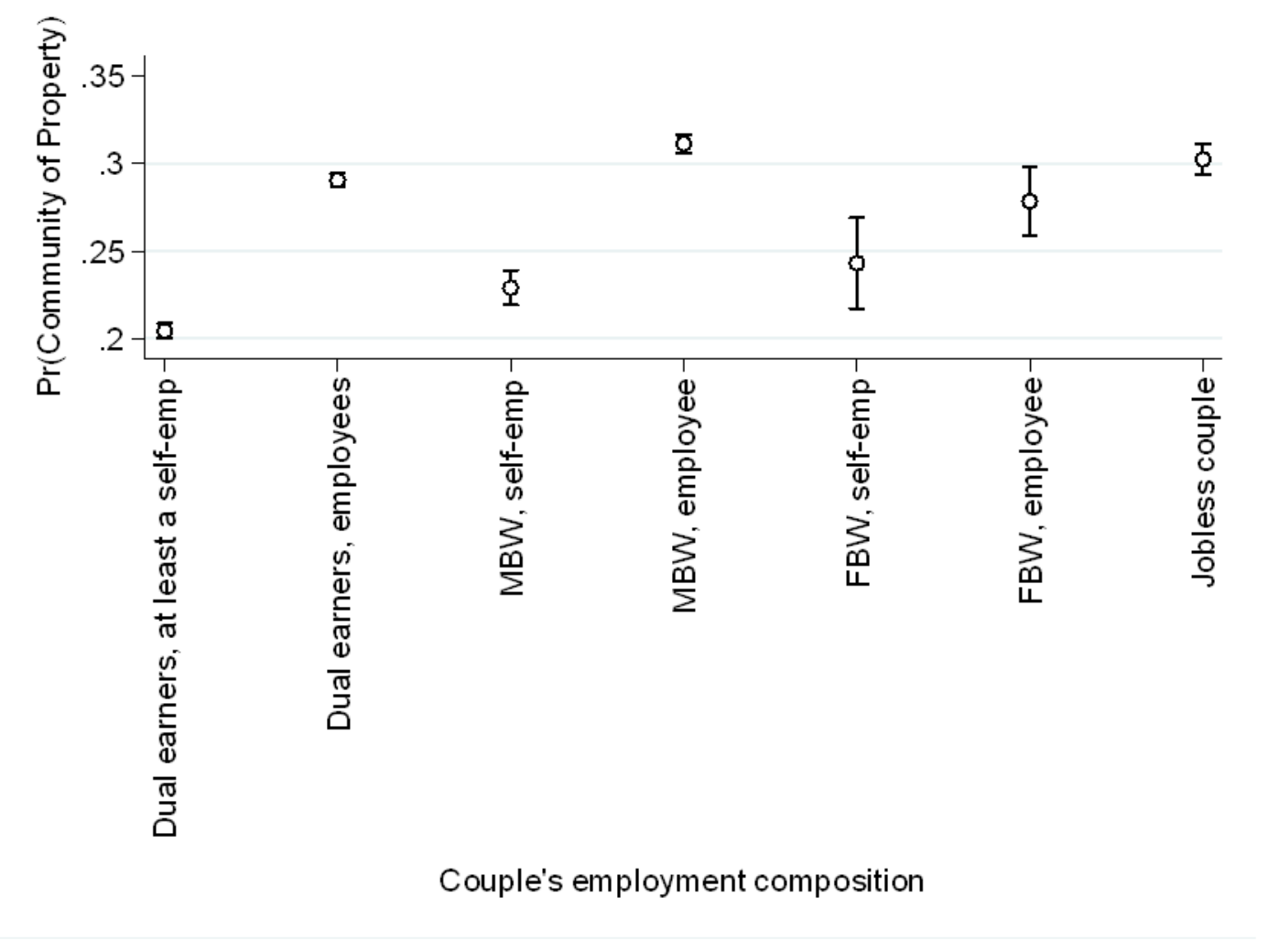

Source. Istat. Marriage register, 2015.

Note. Results from logistic regression Model 2, all controls included. 
DIFFERENCE (a) AMONG SPOUSES, WITH 95\% CONFIDENCE INTERVAL

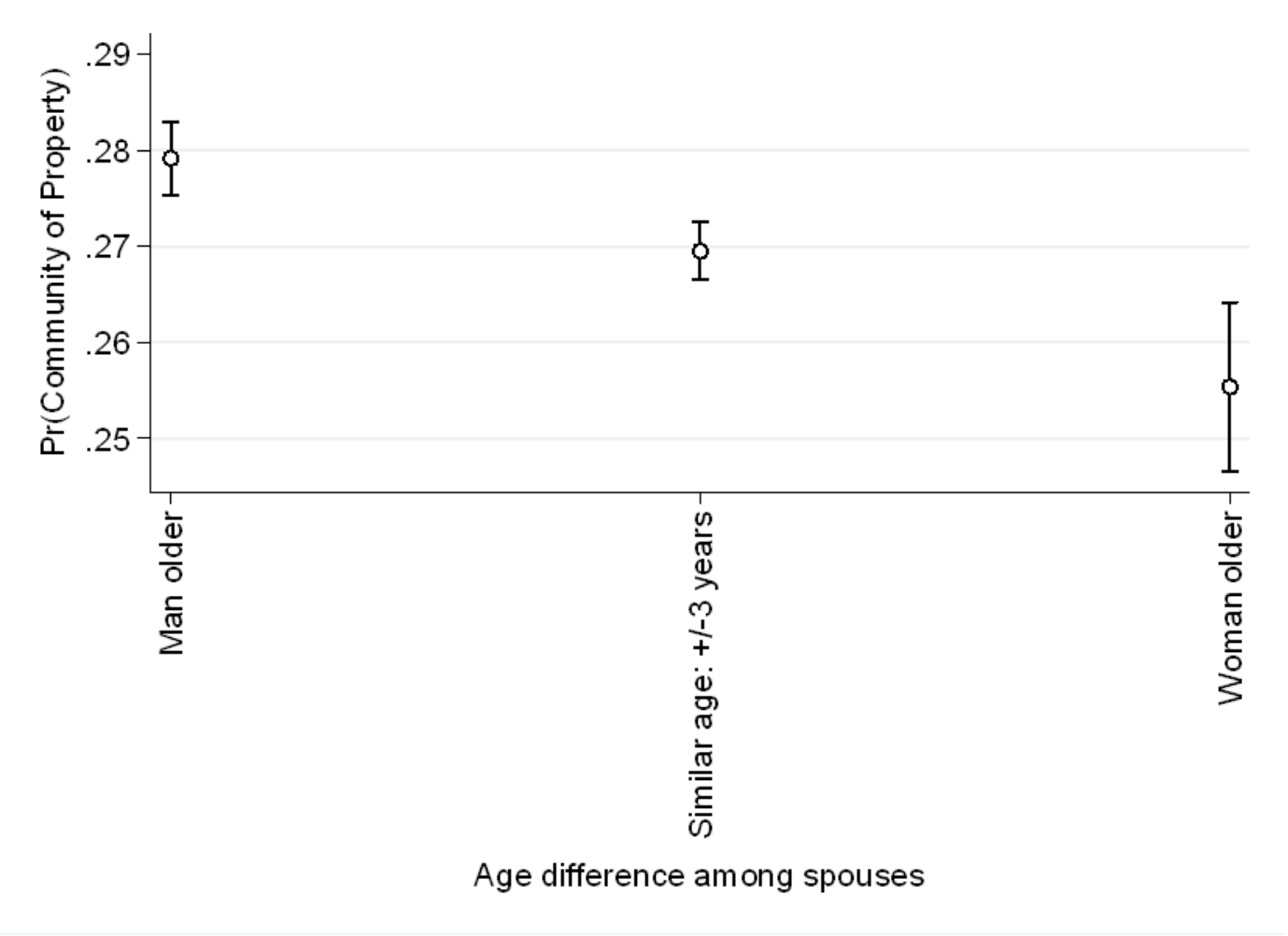

Source. Istat. Marriage register, 2015.

Note. Results from logistic regression Model 2, all controls included.

(a) Age differential is defined as follows: 'Similar age' includes spouses where the difference between male and female ages ranges between -3 and +3 years; 'Man older' includes spouses where man is more than 3 years older than woman; 'Woman older' includes spouses where the woman is more than 3 years older than man. 
Figure 4: AVERAge AdJusted Predictions of OBSERVING COMMUNity OF PROPERTY By COUPLE’S CITIZENSHIP COMPOSITION, WITH 95\% CONFIDENCE INTERVAL

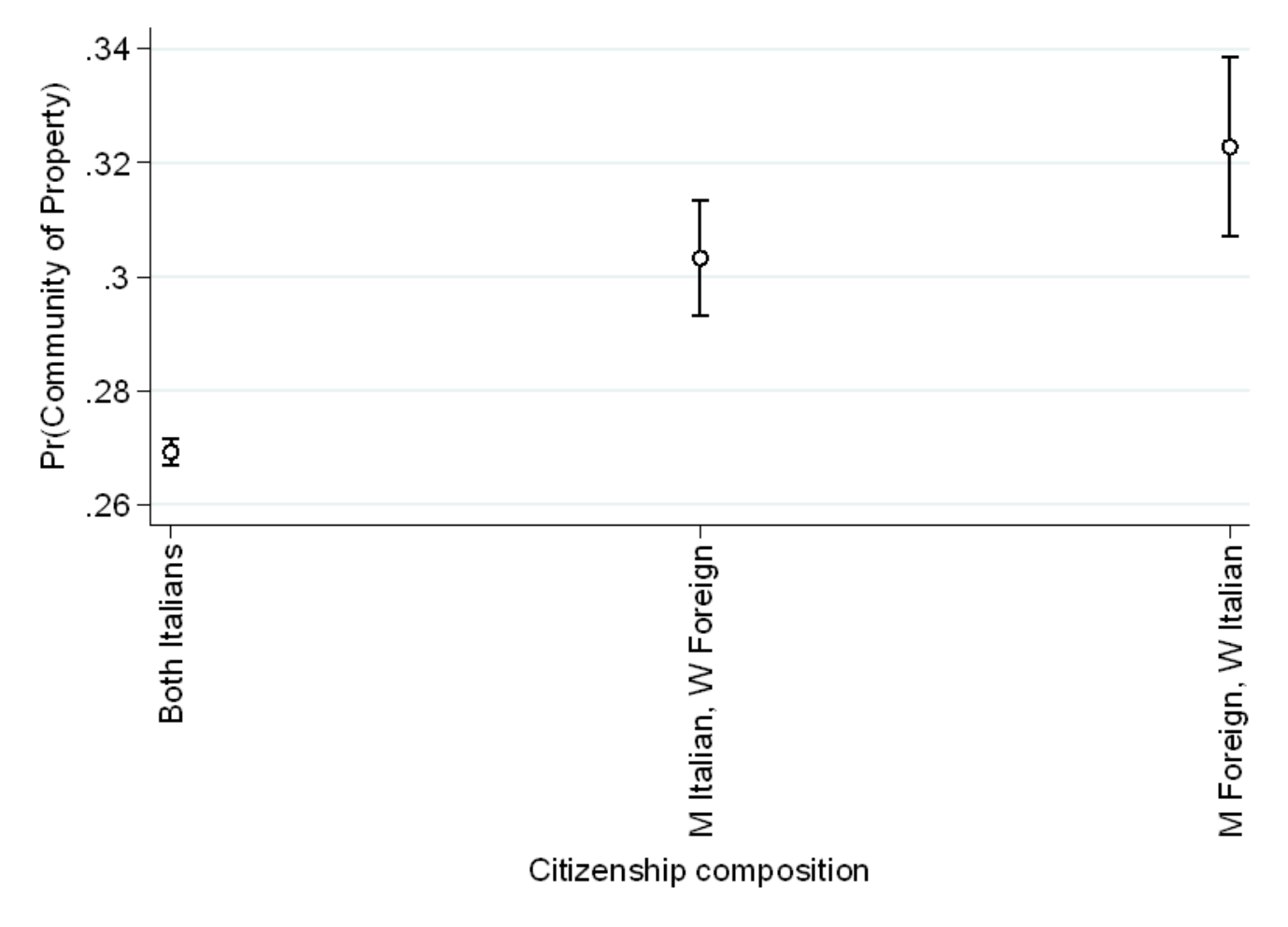

Source. Istat. Marriage register, 2015.

Note. Results from logistic regression Model 2, all controls included. 
Figure 5: AVERAge AdJusted Predictions of OBSERVING COMMUNiTy OF PROPERTY By REGION OF WEDDING CELEBRATION AND WHETHER MUNICIPALITY OF CELEBRATION IS PROVINCIAL CAPITAL CITY, WITH 95\% CONFIDENCE INTERVAL

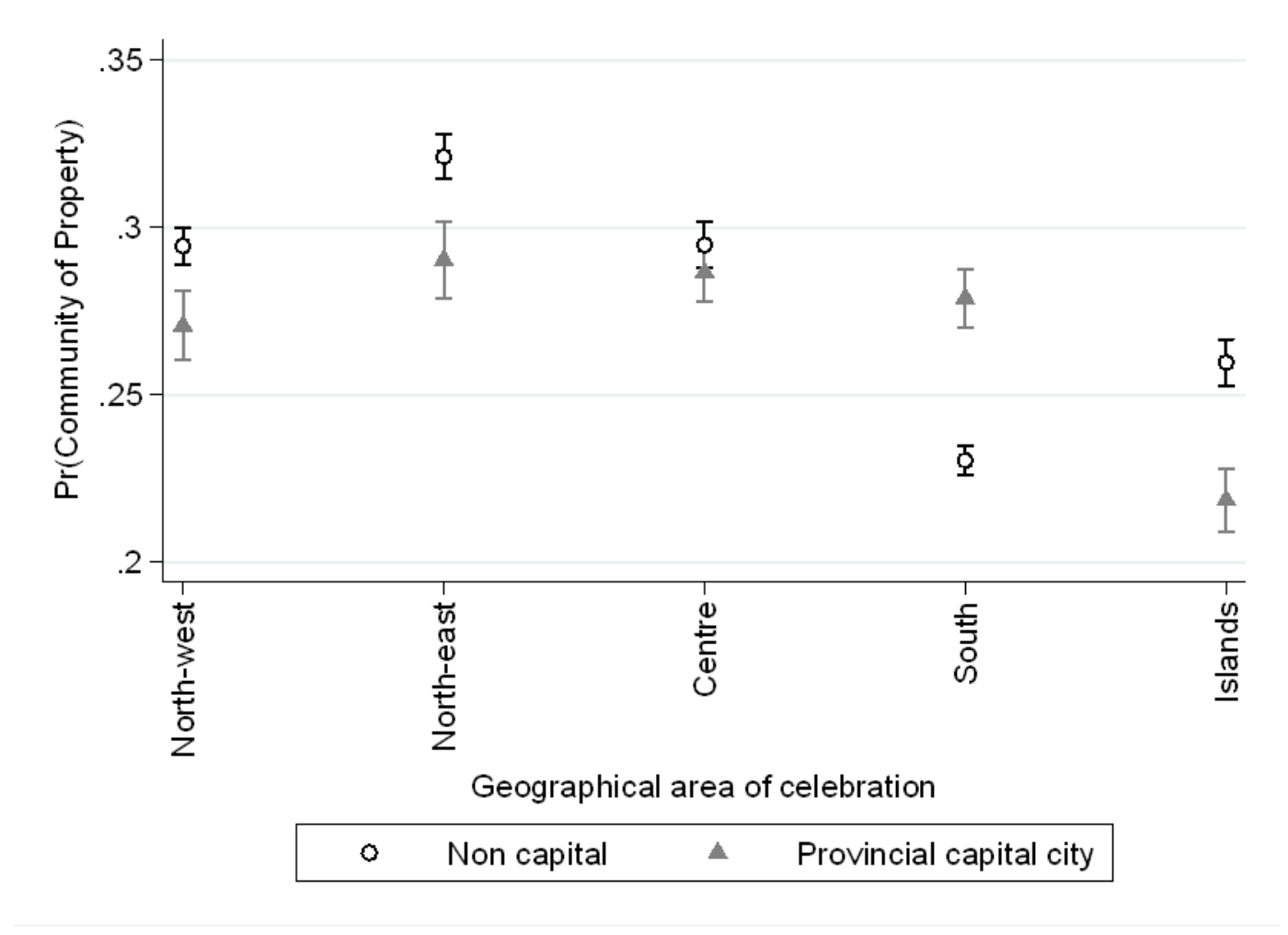

Source. Istat. Marriage register, 2015.

Note. Results from logistic regression Model 2, all controls included.

\section{REFERENCES}

Aassve, A., Fuochi, G., \& Mencarini, L. (2014). Desperate Housework Relative Resources, Time Availability, Economic Dependency, and Gender Ideology Across Europe. Journal of Family Issues, 35 (8), 1000-1022. doi: 10.1177/0192513X14522248

Altintas, E. \& Sullivan, O. (2016). Fifty years of change updated: Cross-national gender convergence in housework. Demographic Research, 35, 455-470. doi: 10.4054/DemRes.2016.35.16 
Andreoni, J., \& Vesterlund, L. (2001). Which is the fair sex? Gender differences in altruism. Quarterly Journal of Economics, 116 (1), 293-312. Available at: http://EconPapers.repec.org/RePEc:oup:qjecon:v:116:y:2001:i:1:p:293-312.

Arpino, B. \&Tavares, L.P., (2013). Fertility and values in Italy and Spain: A look at regional differences within the European context. Population Review, 52(1).

Arpino, B., Esping-Andersen, G., \& Pessin, L. (2015). How do changes in gender role attitudes towards female employment influence fertility? A macro-level analysis. European Sociological Review, 31 (3), 370-382. doi: 10.1093/esr/jcv002

Attanasio, O., \& Lechene, V. (2002). Tests of income pooling in household decisions. Review of Economic Dynamics, 5(4), 720-748. https://doi.org/10.1006/redy.2002.0191

Barbagli, M. (1993). Comunione o separazione dei beni? I rapporti patrimoniali fra i coniugi in Italia: 1975-1991. Polis, VII(1), 143-160.

Barbagli, M. (1997). La scelta del regime patrimoniale. In Barbagli, M. and Saraceno, C. (Eds), "Lo stato delle famiglie in Italia", il Mulino, Bologna.

Bayot, D., \& Voena, A. (2014). Prenuptial contracts, labor supply and household investments. Available at: http://econweb.umd.edu/ davis/eventpapers/VoenaPrenuptial.pdf.

Becker, G. S. (1991). A Treatise on the Family. Cambridge, MA: Harvard University Press.

Bennett, F. (2013). Researching within-household distribution: Overview, developments, debates, and methodological challenges. Journal of Marriage and Family, 75(3), 582-597. doi:10.11 11/jomf.12020

Bertocchi, G., Brunetti, M., \& Torricelli, C. (2014). Who holds the purse strings within the household? The determinants of intra-family decision making. Journal of Economic Behavior \& Organization, 101, 65-86.

Bianchi, S.M., Casper, L.M., \& Peltola, P.K. (1999). A cross-national look at married women's earnings dependency. Gender Issues, 17(3), 3-33. 
Billari, F.C., \& Liefbroer, A. C. (2016). Why still marry? The role of feelings in the persistence of marriage as an institution. The British Journal of Sociology, 67(3), 516-540. doi: $10.1111 / 1468-4446.12202$.

Bloemen, H. G., \& Stancanelli, E. G. F. (2015). Toyboys or supergirls? An analysis of partners' employment outcomes when she outearns him. Review of Economics of the Household, 13(3), 501-530.

Blood, R. O., \& Wolfe, D. M. (1960). Husbands \& wives: The dynamics of married living. New York: Free Press.

Bryant, A. N. (2003). Changes in attitudes toward women's roles: predicting gender-role traditionalism among college students. Sex Roles, 48:131-42.

Burgess, E.W., \& Locke, H. J. (1945). The family: From institution to companionship. New York: American Book.

Burgoyne, C. B. (1990). Money in marriage: How patterns of allocation both reflect and conceal power. The Sociological Review, 38(4), 634-665.

Burgoyne, C. B., \& Lewis, A. (1994). Distributive justice in marriage: Equality or equity? Journal of Community \& Applied Social Psychology, 4 (2), 101-114. doi: 10.1002/casp.2450040204

Burgoyne, C. B., Clarke, V., Reibstein, J., \& Edmunds, A. (2006). 'All my worldly goods I share with you'? Managing money at the transition to heterosexual marriage. The Sociological Review, 54(4), 619-637. doi: 10.1111/j.1467-954x.2006.00663.x

Cherlin, A.J. (2004). The Deinstitutionalization of American Marriage. Journal of Marriage and Family, 66(4), 848-61. doi: 10.1111/j.0022-2445.2004.00058.x

Coles, M.G., \& Francesconi, M. (2011). On the emergence of toyboys: The timing of marriage with aging and uncertain careers. International Economic Review, 52(3), 825-853.

Davis, K. (1941). Intermarriage in caste societies. American Anthropologist, 43 (3), 376-395. 
De Rose, A. \& Fraboni, R. (2015). Educational assortative mating in Italy: what can Gini's homogamy index still say? Genus, LXXI (No. 2-3), 53-71. doi: 10.4402/genus-687

Eckel, C.C., \& Grossman, P. J. (1998). Are women less selfish than men? Evidence from dictator experiments. The Economic Journal, 108 (448), 726-735. doi: 10.1111/14680297.00311

England, P., and McClintock, E. A. (2009). The gendered double standard of aging in US marriage markets. Population and Development Review, 35(4), 797-816.

Esteve, A., Schwartz, C.R., Van Bavel, J., Permanyer, I., Klesment, M. \& García-Román, J. (2016). The End of Hypergamy: Global Trends and Implications. Population and Development Review, 42(4): 615-625.

Grossbard-Shechtman, A. (1984). A Theory of Allocation of Time in Markets for Labor and Marriage. Economic Journal, 94, 863-82.

Hajnal, J. (1983). Two kinds of pre-industrial household formation system. In R. Wall, J. Robin, and P. Laslett eds., Family forms in Historic Europe. Cambridge: Cambridge University Press, 65-104.

Hakim, C. (2010). Erotic capital. European Sociological Review, 26(5), 499-518.

Härkönen, J. and Dronkers, J. (2006). Stability and change in the educational gradient of divorce. A comparison of seventeen countries. European Sociological Review, 22(5): 501517.

Holland, J. A. (2012). Home and where the heart is: Marriage timing and joint home purchase. European Journal of Population/Revue européenne de Démographie, 28(1), 65-89. Istat (1978). Annuario di statistiche demografiche, 1975, Vol.XXIV, Roma.

Istat (2011). Come cambiano le forme familiari. Anno 2009. Statistiche report. Roma. https://www.istat.it/it/files//2011/09/forme-familiari2009.pdf 
Istat (2015). “Come cambia la vita delle donne. 2004-2014” Temi. Letture statistiche. Roma. https://www.istat.it/it/files//2015/12/come-cambia-la-vita-delle-donne.pdf.

Istat (2016). Matrimoni, separazioni e divorzi. Anno 2015. Statistiche report. Roma. https://www.istat.it/it/files//2016/11/matrimoni-separazioni-divorzi-2015.pdf

Kenney, C. T. (2006). The power of the purse: Allocative systems and inequality in couple households. Gender \& Society, 20(3), 354-381. doi: 10.1177/0891243206286742

Klesment, M., \& Van Bavel, J. (2017). The reversal of the gender gap in education, motherhood, and women as main earners in Europe. European Sociological Review, 33(3): 465-481.

Lauer, S. R., \& Yodanis, C. (2011). Individualized marriage and the integration of resources. Journal of Marriage and Family, 73(3), 669-683. doi:10.1111/j.1741-3737.2011.00836.x

Lersch, P. M. (2017). Individual Wealth and Subjective Financial Well-Being in Marriage: Resource Integration or Separation? Journal of Marriage and Family., 79(5), 1-13 doi: 10.1111/jomf.12406

Lesthaeghe, R. \& Neels, K. (2002). From the first to the second demographic transition: An interpretation of the spatial continuity of demographic innovation in France, Belgium and Switzerland. European Journal of Population, 18 (4), 325-360. doi: 10.1023/A:1021125800070

Lott, Y. (2017). When My Money Becomes Our Money: Changes in Couples’ Money Management. Social Policy and Society, 16(2), 199-218. doi: https://doi.org/10.1017/S1474746415000688

Lundberg, S. \& Pollak, R.A. (1996). Bargaining and distribution in marriage. The Journal of Economic Perspectives, 139-158.

Lundberg, S.J., Pollak, R.A., \& Wales, T.J. (1997). Do husbands and wives pool their resources? Evidence from the United Kingdom child benefit. Journal of Human resources, 463-480. 
Merton, R.K. (1941). Intermarriage and the social structure: Fact and theory. Psychiatry, 4 (3), $361-374$.

Pahl, J. (1995). His money, her money: Recent research on financial organisation in marriage. Journal of economic psychology, 16 (3), 361-376.

Pahl, J. (2005). Individualisation in couple finances: Who pays for the children?. Social Policy and Society, 4(04), 381-391. doi: https://doi.org/10.1017/S1474746405002575

Parsons, T, \& Bales, R. (1955). Family, socialization and interaction process. New York: The Free Press.

Pepin, J.R. (2017, May 8). Normative Beliefs about Money in Families: Balancing Togetherness, Autonomy, and Equality. Retrieved from osf.io/preprints/socarxiv/6aqse

Pocar, V., \& Ronfani, P. (1978). Family law in Italy: Legislative innovations and social change. Law and Society Review, 607-643.

Pollak, R.A. (1985). A transaction cost approach to families and households. Journal of economic Literature, 23(2), 581-608.

Raley, S.B., Mattingly, M.J., \& Bianchi, S.M. (2006). How Dual Are Dual - Income Couples? Documenting Change From 1970 to 2001. Journal of Marriage and Family, 68(1), 11-28.

Rešetar, B. (2008). Matrimonial Property in Europe: A Link between Sociology and Family Law. Electronic Journal of Comparative Low, 12 (3), 1-10.

Rheinstein, M. (1975). Division of Marital Property. Willamette Low Journal, 12, 413-440.

Rosina, A., \& Fraboni, R. (2004). Is marriage losing its centrality in Italy? Demographic Research, Volume 11, September. DOI: 10.4054/DemRes.2004.11.6

Ruiu, G., \& Breschi, M. (2017). " Let's talk about love": An analysis of the religious and economic factors determining the choice of marital property regime in Italy. Demographic Research, 36(29), 851-862. doi: 10.4054/DemRes.2017.36.29 
Saraceno, C. (1994). The ambivalent familism of the Italian welfare state. Social Politics, 1(1), $60-82$.

Strozza, S., \& De Santis, G. (2017). Rapporto sulla popolazione. Le molte facce della presenza straniera in Italia, (eds.), Associazione Italiana per gli Studi di Popolazione, chap.3, Il Mulino, Bologna.

Sweeney, M. M., \& M. Cancian (2004). The changing importance of white women's economic prospects for assortative mating. Journal of Marriage and Family, 66(4), 1015-1028. doi: 10.1111/j.0022-2445.2004.00073.x

Tichenor, V.J. (1999). Status and income as gendered resources: The case of marital power. Journal of Marriage and the Family, 61, 638-650.

Tichenor, V. (2005). Maintaining men's dominance: Negotiating identity and power when she earns more. Sex Roles, 53 (3-4), 191-205.

Treas, J. (1993). Money in the bank: Transaction costs and the economic organization of marriage. American Sociological Review, 58(5): 723-734.

Vignoli, D., \& Salvini, S. (2014). Religion and union formation in Italy: Catholic precepts, social pressure, and tradition. Demographic Research, 31, 1079-1106. doi: 10.4054/DemRes.2014.31.35

Vignoli, D., Tocchioni, V., \& Salvini, S. (2016). Uncertain lives: Insights into the role of job precariousness in union formation in Italy. Demographic Research, 35(10), 253-282. doi: 10.4054/DemRes.2016.35.10

Vitali, A., \& Arpino, B. (2016). Who brings home the bacon? The influence of context on partners' contributions to the household income. Demographic Research, 35(41), 12131244. doi: 10.4054/DemRes.2016.35.41

Vogler, C. (1998). Money in the household: some underlying issues of power. The Sociological Review, 46(4): 687-713.doi: 10.1111/1467-954x.00136 
Vogler, C., \& Pahl, J. (1993). Social and economic change and the organisation of money within marriage. Work, Employment \& Society, 7(1), 71-95. doi: https://doi.org/10.1177/095001709371004

Vogler, C., Brockmann, M., \& Wiggins, R. D. (2008). Managing money in new heterosexual forms of intimate relationships. The journal of socio-economics, 37(2), 552-576.

West, C., \& Zimmerman, D. H. (1987). Doing gender. Gender \& society, 1(2), 125-151.

Yodanis, C., \& Lauer, S. (2007). Managing money in marriage: Multilevel and cross-national effects of the breadwinner role. Journal of Marriage and Family, 69 (5), 1307-1325. doi: 10.1111/j.1741-3737.2007.00449.x 